Review

\title{
Immune Modulation by Vitamin D and Its Relevance to Food Allergy
}

\author{
Noor H. A. Suaini ${ }^{1,2}$, Yuxia Zhang ${ }^{3,4}$, Peter J. Vuillermin ${ }^{1,5,6}$, Katrina J. Allen ${ }^{1,2,7,8, *}$ and \\ Leonard C. Harrison ${ }^{3,4}$ \\ ${ }^{1}$ Murdoch Childrens Research Institute, The Royal Children's Hospital, Parkville, VIC 3052, \\ Australia; E-Mails: noor.suaini @ mcri.edu.au (N.H.A.S.); peter.vuillermin @ deakin.edu.au (P.J.V.) \\ 2 Department of Paediatrics, University of Melbourne, Parkville VIC 3052, Australia \\ 3 The Walter and Eliza Hall Institute of Medical Research, Parkville, VIC 3052, Australia; \\ E-Mails: yzhang@wehi.edu.au (Y.Z.); harrison@wehi.edu.au (L.C.H.) \\ ${ }^{4}$ Department of Medical Biology, University of Melbourne, Parkville, VIC 3052, Australia \\ ${ }^{5}$ Child Health Research Unit, Barwon Health, Geelong, VIC 3220, Australia \\ ${ }^{6}$ Deakin University, Geelong, VIC 3220, Australia \\ ${ }^{7}$ Department of Allergy and Immunology, The Royal Children's Hospital, Parkville, VIC 3052, \\ Australia \\ ${ }^{8}$ University of Manchester, Oxford Road, Manchester M13 9PL, UK \\ * Author to whom correspondence should be addressed; E-Mail: katie.allen@ mcri.edu.au; \\ Tel.: +61-3-9936-6752.
}

Received: 8 May 2015 / Accepted: 20 July 2015 / Published: 27 July 2015

\begin{abstract}
Apart from its classical function in bone and calcium metabolism, vitamin D is also involved in immune regulation and has been linked to various cancers, immune disorders and allergic diseases. Within the innate and adaptive immune systems, the vitamin D receptor and enzymes in monocytes, dendritic cells, epithelial cells, $\mathrm{T}$ lymphocytes and B lymphocytes mediate the immune modulatory actions of vitamin D. Vitamin D insufficiency/deficiency early in life has been identified as one of the risk factors for food allergy. Several studies have observed an association between increasing latitude and food allergy prevalence, plausibly linked to lower ultraviolet radiation (UVR) exposure and vitamin D synthesis in the skin. Along with mounting epidemiological evidence of a link between vitamin $\mathrm{D}$ status and food allergy, mice and human studies have shed light on the modulatory properties of vitamin $\mathrm{D}$ on the innate and adaptive immune systems. This review will summarize the literature on the metabolism and immune modulatory properties of vitamin $\mathrm{D}$, with particular reference to food allergy.
\end{abstract}


Keywords: vitamin D; innate immunity; adaptive immunity; food allergy; $1,25(\mathrm{OH})_{2} \mathrm{D}_{3}$;

T cells; inflammation; metabolism; deficiency

\section{Introduction}

Classically notable for its effects on calcium metabolism and bone mineralisation, vitamin D is now recognised to have protean effects, including on the immune system. The immunological significance of vitamin D was first recognised when the vitamin D receptor (VDR) was identified in lymphocytes [1,2]. Vitamin D deficiency has been associated with various immune diseases, including allergic [3,4] and autoimmune diseases [5,6]. In particular, an increase in the population prevalence of vitamin D insufficiency has been observed in parallel with an increase in food allergy [7]. Food allergy has been associated with indicators of vitamin D insufficiency, in particular vitamin D synthesis in the skin and increasing latitude, which may be due to lower UV exposure [8,9]. Additionally, findings from our HealthNuts study, a population-based study of food allergy in Melbourne infants, suggest a potential role of vitamin D insufficiency at 12 months of age in the development of food allergy [7]. However, the biological mechanisms underlying these epidemiological associations remain unclear, and some research has suggested that vitamin D excess may also increase the risk of abnormal immune responses and an increased risk of food allergy [10].

The VDR regulates the actions of immune cells, such as monocytes, dendritic cells (DCs), T and B cells, in an interplay between the innate and adaptive immune systems [11-14]. As the first barrier of defence, the innate immune system protects against invading microorganisms [15]. Several mechanisms have been postulated for the effects of vitamin D on the innate and adaptive immune system - to reduce inflammation, promote immune tolerance and enhance gut epithelial integrity - but the mechanisms by which vitamin D may influence the risk of food allergy are not clear. In this review, the metabolism of vitamin $\mathrm{D}$ and its immune modulatory properties in relation to food allergy will be summarised.

\section{Regulation and Metabolism of $1,25(\mathrm{OH})_{2} \mathrm{D}$}

vitamin $\mathrm{D}$ is a fat-soluble vitamin that can be acquired through dietary sources, although most is produced in the skin following sunlight exposure. Vitamin D is the general term encompassing both vitamin $\mathrm{D}_{2}$ and $\mathrm{D}_{3}$. Vitamin $\mathrm{D}_{2}$, also known as ergocalciferol, is produced when ultraviolet light, in particular the UVB band of sunlight, acts on ergosterol, which is found mainly in yeast and plants $[16,17]$. On the other hand, vitamin $\mathrm{D}_{3}$, cholecalciferol, is formed when 7-dehydrocholesterol found in the skin absorbs the UVB radiation $[16,18]$. Both vitamin $\mathrm{D}_{2}$ and $\mathrm{D}_{3}$ generally undergo the same processes to form calcitriol $\left(1,25(\mathrm{OH})_{2} \mathrm{D}\right)$. However, due to differences in their chemical structures, there are minor differences in the types of metabolites produced and the sites of hydroxylation [19]. Studies have shown that vitamin D binding protein (VDBP) has a higher affinity for vitamin $\mathrm{D}_{3}$ than $\mathrm{D}_{2}$ [20]. This results in vitamin $\mathrm{D}_{3}$ having a longer half-life and being more potent than $\mathrm{D}_{2}$ [21-23]. In this section, the metabolic processes will be generalised to include both forms of vitamin $\mathrm{D}$. 


\subsection{Renal Synthesis of $1,25(\mathrm{OH})_{2} \mathrm{D}$}

Sterol 27-hydroxylase (CYP27A1) and vitamin D 25-hydroxylase (CYP2R1), two cytochromes expressed in the liver, hydroxylate vitamin $\mathrm{D}$ to 25-hydroxyvitamin D (25(OH)D) [24]. Other cytochrome P450 vitamin D 25 hydroxylases, such as CYP3A4 [25-27] and CYP2J2 [28], have also been shown to have some 25 hydroxylase activity. In the kidney, $25(\mathrm{OH}) \mathrm{D}$ then undergoes further hydroxylation by 25-hydroxyvitamin D-1 $\alpha$-hydroxylase (CYP27B1) to produce the biologically-active form of vitamin D, 1,25-dihydroxyvitamin D $\left(1,25(\mathrm{OH})_{2} \mathrm{D}\right)$ (Figure 1). Vitamin D and its plasma metabolites are mostly transported by VDBP (encoded by the $G C$ gene), with a smaller percentage bound to albumin [29]. On reaching the target cells, $1,25(\mathrm{OH})_{2} \mathrm{D}$ dissociates from the VDBP, diffuses into the cell and binds to the nuclear VDR to initiate gene transcription [30-33]. It is worth noting that the VDBPs do not actually facilitate $1,25(\mathrm{OH})_{2} \mathrm{D}$ entry into the cell [34]. Finally, 25(OH)D and $1,25(\mathrm{OH})_{2} \mathrm{D}$ may be metabolically inactivated through hydroxylation by 24-hydroxylase (CYP24A1), hence limiting its availability $[35,36]$.

Renal production of $1,25(\mathrm{OH})_{2} \mathrm{D}$ is tightly regulated by a feedback loop at the cellular level, primarily through the actions of parathyroid hormone (PTH) and fibroblast growth factor 23 (FGF-23) (Figure 1). In response to low circulating calcium levels, PTH is secreted by the parathyroid gland to stimulate CYP27B1 production by primary renal tubules [36-38]. As renal production of $1,25(\mathrm{OH})_{2} \mathrm{D}$ increases, VDR binds to $C Y P 27 B 1$ promoter to repress its expression and, thereby, production of $1,25(\mathrm{OH})_{2} \mathrm{D}$. $1,25(\mathrm{OH})_{2} \mathrm{D}$ increases the uptake of calcium and inhibits production and secretion of PTH [38].

While PTH is essential in maintaining blood calcium levels, FGF-23 plays a role in mineral homeostasis determined by genes regulating serum phosphate and vitamin D metabolism. Increased serum phosphate induces a marked increase in FGF-23 expression and FGF-23 secretion by bone cells [39]. Concurrently, FGF-23 action reduces renal expression of $C Y P 27 B 1$, leading to decreased serum $1,25(\mathrm{OH})_{2} \mathrm{D}$ [40]. FGF-23 negatively regulates CYP27B1 activity together with the transmembrane protein Klotho, which acts as a co-receptor essential for the activation of FGF signaling by FGF-23 [38-40]. Renal $1,25(\mathrm{OH})_{2} \mathrm{D}$ concentrations are thus tightly regulated by a network of feedback loops, which includes the inhibition of CYP27B1 by FGF-23/Klotho, activation of CYP27B1 by low circulating calcium and increased PTH secretion and activation of CYP24A1 to initiate degradation of metabolites [12,32,37,41,42].

\subsection{Extra-Renal Synthesis of $1,25(\mathrm{OH})_{2} \mathrm{D}$}

Extra-renal synthesis of $1,25(\mathrm{OH})_{2} \mathrm{D}$ is present in many tissues, such as parathyroid glands, keratinocytes and immune cells [37,38]. For example, CYP27B1 is expressed in T cells [43], activated macrophages and DCs [43-45], allowing the formation of $1,25(\mathrm{OH})_{2} \mathrm{D}$ in the immune cells. Unlike in the kidney, regulation of extra-renal CYP27B1 is generally under the control of immune stimuli and not by the classical feedback loop involving PTH and FGF-23 [13,38,46]. In macrophages, CYP27B1 is induced after Toll-like receptor (TLR) ligation or stimulation by interferon- $\gamma$ (IFN- $\gamma$ ) [37,45,47]. CYP24A1 is transcribed as an enzymatically-inactive splice variant, which prevents the breakdown of $25(\mathrm{OH}) \mathrm{D}$ and $1,25(\mathrm{OH})_{2} \mathrm{D}[48,49]$. As a result, overexpression of unregulated CYP27B1 in macrophages may potentially lead to excessive $1,25(\mathrm{OH})_{2} \mathrm{D}$ production, contributing to pathological 
diseases, such as sarcoidosis [49,50]. Sites of extra-hepatic 25-hydroxylase activity have also been reported [51], with the detection of CYP27 mRNA in the bone [52] and white blood cells [53,54]. Novel extra-hepatic P450 enzymes, such as CYP2S1 and CYP2U1, have also been identified [55].

\subsection{Genomic and Non-Genomic (Rapid) Signaling}

Binding of $1,25(\mathrm{OH})_{2} \mathrm{D}$ to the VDR occurs with high affinity and selectivity, preventing the precursor, $25(\mathrm{OH}) \mathrm{D}$, from activating the VDR under normal circumstances [56]. The VDR-1,25(OH) ${ }_{2} \mathrm{D}$ complex heterodimerizes with retinoid $\mathrm{X}$ receptor $(\mathrm{RXR})$ to bind to the vitamin $\mathrm{D}$ response element (VDRE) located in the promoter region of vitamin D-responsive genes. This leads to recruitment of co-activators (e.g., SRC1, CBP, MED1) or co-repressors (e.g., NcoR, SMRT) to regulate transcription of $1,25(\mathrm{OH})_{2} \mathrm{D}$-responsive genes [57]. However, the VDR may also regulate gene expression in a $1,25(\mathrm{OH})_{2} \mathrm{D}$-independent manner via recruitment of gene-specific co-regulatory complexes [56]. The VDR can be post-translationally modified by phosphorylation, although the functional significance of this is uncertain $[58,59]$.

While the genomic signaling is reliant on responses to the nuclear VDR, non-genomic signaling utilises different signal transduction pathways [60]. It was demonstrated that rapid signaling is mediated through VDRs associated within caveolae or lipid rafts on the plasma membrane of certain cells [61]. Examples of systems that involve rapid signaling include intestinal calcium transport in a vitamin D-replete chick [60] and $1,25(\mathrm{OH})_{2} \mathrm{D}_{3}$ modulation of osteoblast ion channel responses [62]. Non-genomic signaling pathways triggered by $1,25(\mathrm{OH})_{2} \mathrm{D}_{3}$ may be mediated through activation of second messengers, such as protein kinase $\mathrm{C}$ (PKC) [63], intracellular increase in calcium and modulation of phospholipase $\mathrm{C}$ and adenylate cyclase [64]. In particular, $1,25(\mathrm{OH})_{2} \mathrm{D}_{3}$ has been shown to directly activate PKC at physiological concentrations, with PKC acting as a membrane-associated receptor for the hormone [65]. Two isoforms of PKC, PKC $\beta I$ and PKC $\zeta$, have been shown to be involved in $1,25(\mathrm{OH})_{2} \mathrm{D}_{3}$ induction of rat cytochrome P450C24 (CYP24) expression, while the other $\mathrm{PKC}$ enzymes, $\mathrm{PKC} \alpha, \mathrm{PKC} \delta$ and $\mathrm{PKC} \varepsilon$, were not essential [66,67]. Using human embryonic kidney 293 T cells, Nutchey et al. [66] found that JNK activity, but not extracellular signal-regulated kinase (ERK) $1 / 2$, was required for $1,25(\mathrm{OH})_{2} \mathrm{D}_{3}$ to induce the expression of CYP24 gene. However, the opposite was observed in monkey kidney fibroblast COS-1 cells, in which JNK was not found to mediate CYP24, but instead, either ERK1/ERK2 or ERK5 modules or both were required [68]. Given that CYP24 null mice exhibited elevated $1,25(\mathrm{OH})_{2} \mathrm{D}_{3}$ levels due to impaired catabolism, regulation of CYP24 expression may prevent $1,25(\mathrm{OH})_{2} \mathrm{D}_{3}$-induced toxicity [69-71].

\subsection{Definitions of Vitamin D Status}

$25(\mathrm{OH}) \mathrm{D}_{3}$ has a half-life of approximately 15 days as compared to only $15 \mathrm{~h}$ for $1,25(\mathrm{OH})_{2} \mathrm{D}_{3}[72]$. Thus, serum $25(\mathrm{OH}) \mathrm{D}_{3}$ circulates at a much higher concentration and is typically used as a marker of vitamin D status. Australian guidelines stipulated that mild vitamin D deficiency is defined as a serum $25(\mathrm{OH}) \mathrm{D}$ concentration of 30-49 nmol/L, moderate deficiency as $12.5-29 \mathrm{nmol} / \mathrm{L}$ and severe vitamin $\mathrm{D}$ deficiency as $<12.5 \mathrm{nmol} / \mathrm{L}$ [73]. The optimal level of serum $25(\mathrm{OH}) \mathrm{D}$ is unknown, although concentrations of $\geqslant 50 \mathrm{nmol} / \mathrm{L}$ are generally considered adequate [17,74]. Several studies found a positive correlation between $1,25(\mathrm{OH})_{2} \mathrm{D}_{3}$ and $25(\mathrm{OH}) \mathrm{D}_{3}[75-77]$. Nordin et al. [76] suggested that the 
relationship between the two metabolites is biphasic; positive when $25(\mathrm{OH}) \mathrm{D}_{3}$ is normal and negative when $25(\mathrm{OH}) \mathrm{D}_{3}$ is below the normal range. However, findings from some earlier studies suggested that serum concentrations of the two vitamin D metabolites are not correlated and attributed findings of a positive relationship to methodological errors $[78,79]$.

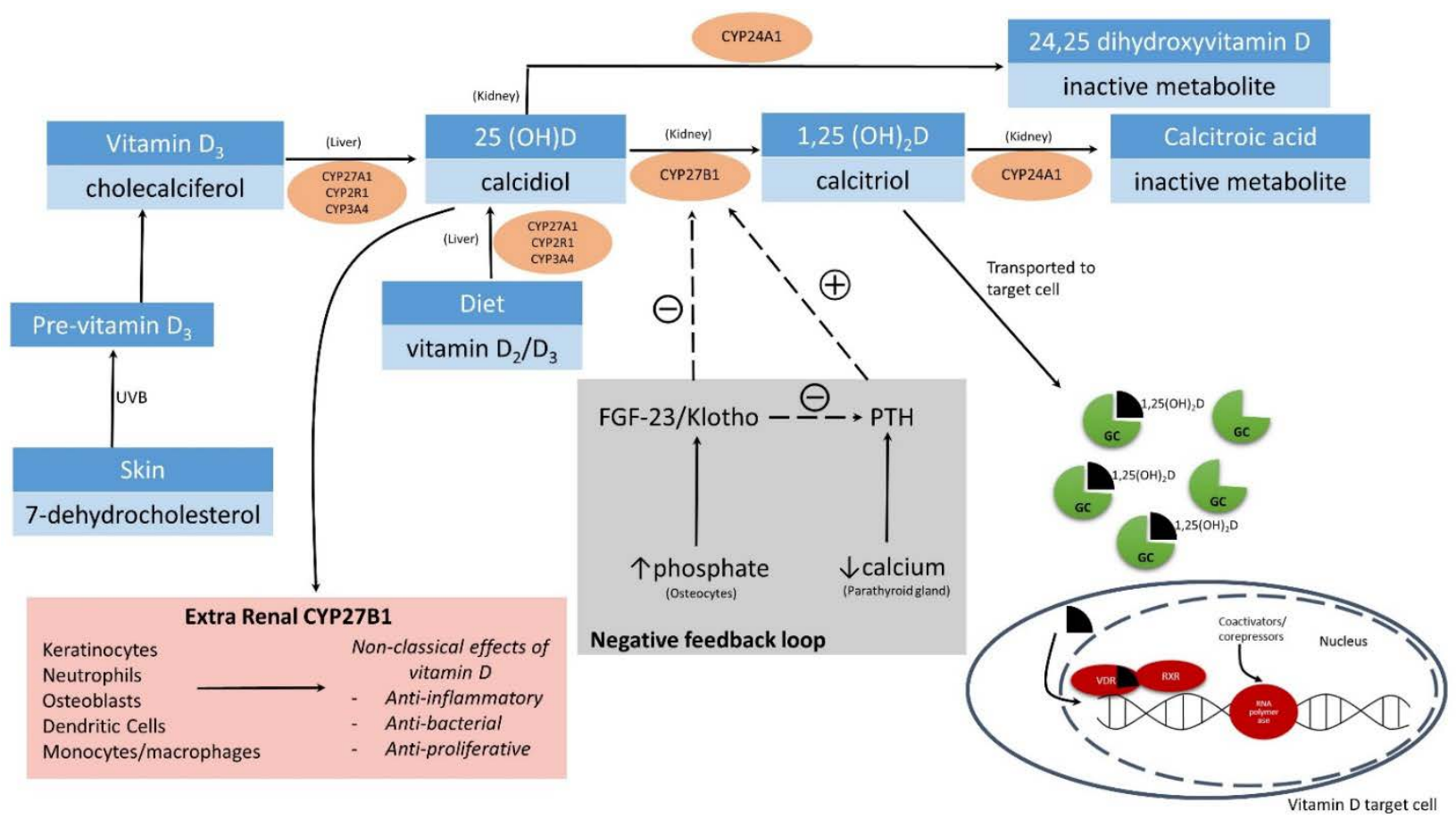

Figure 1. vitamin D metabolism and associated enzymes. Vitamin D from the diet and skin undergoes several hydroxylation steps to produce the biologically-active form of vitamin $\mathrm{D}, 1,25(\mathrm{OH})_{2} \mathrm{D}$. In circulation, $1,25(\mathrm{OH})_{2} \mathrm{D}$ bound to the vitamin $\mathrm{D}$ binding protein (encoded by $G C$ gene) is transported to the vitamin D target cells. Once it reaches the target cell, it dissociates from the binding protein and translocates to the nucleus, where it binds to the vitamin D receptor (VDR) and heterodimerizes with the retinoid $\mathrm{X}$ receptor (RXR). Recruitment of transcription factors results in the activation or repression of gene transcription. $1,25(\mathrm{OH})_{2} \mathrm{D}$ synthesis is regulated by feedback mechanisms involving fibroblast growth factor 23 (FGF-23) and parathyroid hormone (PTH). In the parathyroid gland, low serum calcium levels induce the secretion of PTH and activation of CYP27B1, resulting in the production of $1,25(\mathrm{OH})_{2} \mathrm{D}$. As a second feedback loop, a high serum phosphate level triggers the secretion of FGF-23 from osteocytes and inhibits CYP27B1 synthesis. Activation of CYP24A1 also converts the bioactive vitamin $\mathrm{D}_{3}$ into inactive metabolites for secretion in bile.

\section{Regulation of Immune Function by Vitamin D}

\subsection{Innate Immunity}

The innate immune system, as the first barrier of immune defence, guards against invading foreign microorganisms and contributes to the maintenance of immune homeostasis [15]. Foreign 
microorganisms express pathogen-associated molecular patterns (PAMPs) that are recognised by pattern recognition receptors, such as TLRs expressed by the innate immune cells [80]. Depending on which TLRs are activated by PAMPs, the innate immune system will then mediate responses, such as the production of antimicrobial peptides and cytokines and the apoptosis of host cells [80]. Vitamin D has been found to induce antimicrobial peptide synthesis in the innate immune cells, to dampen excessive inflammation and to inhibit the production of pro-inflammatory cytokine [81,82]. In preventing infection, vitamin D induces antimicrobial peptide synthesis [83,84] through VDREs present in the promoter regions of genes encoding antimicrobial peptides cathelicidin (hCAP18) and $\beta$-defensin $(D E F B)$ [85]. Production of cathelicidin, which is upregulated in the presence of $1,25(\mathrm{OH})_{2} \mathrm{D}_{3}$ [85], is essential for antimicrobial defences and the cytotoxic activity of natural killer cells against tumour cells $[82,86]$. Additionally, cathelicidin has also been shown to mediate vitamin D-induced autophagy in monocytes/macrophages $[87,88]$. Yuk et al. [88] demonstrated that $1,25(\mathrm{OH})_{2} \mathrm{D}_{3}$ is required for co-localization of mycobacterial phagosomes with autophagosomes. Another vitamin D-related mechanism postulated to prevent infection is enhancement of nitric oxide production by macrophages and expression of inducible nitric oxide synthase [89]. Although this has been shown in mouse models, its significance in humans is still questionable, as the amount of nitric oxide produced in vitro by human macrophages was negligible [90].

Complementing its antimicrobial properties, $1,25(\mathrm{OH})_{2} \mathrm{D}_{3}$ acts to suppress excessive inflammation. $1,25(\mathrm{OH})_{2} \mathrm{D}_{3}$ represses the expression of TLRs [45,84] and inhibits the production of pro-inflammatory cytokines by DCs and innate immune cells [91,92]. VDR activation inhibits DC differentiation and maturation, which is reflected by decreased surface expression of MHC class II, co-stimulatory molecules (CD40, CD80 and CD86) and other maturation-induced surface markers, such as CD83 [93-96]. As immature DCs are 'tolerogenic', inhibition of DC differentiation by $1,25(\mathrm{OH})_{2} \mathrm{D}_{3}$ contributes to $\mathrm{T}$ cell tolerance and adaptive immune homeostasis (discussed below).

Consistent with its anti-inflammatory role, $1,25(\mathrm{OH})_{2} \mathrm{D}_{3}$ may also inhibit type 1 T-helper (Th1) cell responses by suppression of IL-12 production by DCs [94,97]. This is due to disruption by the $1,25(\mathrm{OH})_{2} \mathrm{D}_{3}$-VDR complex of NF- $\mathrm{KB}$ binding to IL-12 promoter regions and, hence, inhibition of IL-12 mRNA expression [95,98]. While IL-12 synthesis is suppressed, IL-10 production by DCs is enhanced, together with induction of type 1 (IL-10 secreting) regulatory cells (Tr1) [94,99] and a shift from a Th1 to type 2 T-helper (Th2) phenotype [100]. Enhanced IL-10 production has also been observed in mouse mast cells in vitro in the presence of $1,25(\mathrm{OH})_{2} \mathrm{D}_{3}$ [101]. Augmented IL-10 synthesis contributing to a suppressed mast cell-mediated inflammation, may dampen IgE-dependent allergic reactions [102]. Clinically, the beneficial effects of vitamin D were observed in a recent clinical trial that showed the resolution of inflammatory responses in 95 participants treated with adjunctive vitamin D supplementation in addition to standard tuberculous therapy [103].

\subsection{Adaptive Immunity}

Signals from innate immune cells determine the fate of differentiating T cells and B cells [104,105]. Hewison [106] suggested four plausible mechanisms through which serum 25(OH)D may modulate T cell function: (i) direct effects mediated via systemic $1,25(\mathrm{OH})_{2} \mathrm{D}$; (ii) indirect effects via antigen presentation by monocytes and macrophages to T cells, mediated by DC expression of CYP27B1 and 
intracrine synthesis of $1,25(\mathrm{OH})_{2} \mathrm{D}$; (iii) direct effects of $1,25(\mathrm{OH})_{2} \mathrm{D}$ on $\mathrm{T}$ cells following the synthesis of the biologically-active vitamin D by CYP27B1-expressing monocytes or DCs (paracrine mechanism); and (iv) intracrine conversion of $25(\mathrm{OH}) \mathrm{D}$ to $1,25(\mathrm{OH})_{2} \mathrm{D}$ by $\mathrm{T}$ cells.

A group of $\mathrm{T}$ cells that may also be activated by $1,25(\mathrm{OH})_{2} \mathrm{D}$ are regulatory $\mathrm{T}$ cells (Tregs). Tregs suppress other immune cells and contribute to the maintenance of immune homeostasis by a range of mechanisms, including cell to cell contact and secretion of anti-inflammatory factors, such as IL-10 and TGF- $\beta$ [107-109]. They can be classified into two major subtypes: those that are naturally occurring in the thymus and those derived from peripheral CD4 ${ }^{+} \mathrm{T}$ cells following antigen stimulation [110,111]. Peripheral differentiation of Tregs is induced when $1,25(\mathrm{OH})_{2} \mathrm{D}_{3}$ represses the differentiation and maturation of DCs to generate tolerogenic immature DCs $[42,106]$. $1,25(\mathrm{OH})_{2} \mathrm{D}_{3}$ can also bind to the retinoic acid receptor to promote peripheral Treg differentiation from naive $\mathrm{CD}^{+}{ }^{+} \mathrm{T}$ cells [112] into IL-10-secreting-Tr1 Tregs [11]. This suppressive activity may also be induced by VDR agonists [113]. In a clinical trial of 46 individuals, 140,000 IU of vitamin D supplementation were associated with an increased Treg frequency in peripheral circulation after four weeks [114].

Studies have also shown that $\mathrm{T}$ cell proliferation and function is inhibited in response to $1,25(\mathrm{OH})_{2} \mathrm{D}_{3}$ (calcitriol) $[94,97,115,116]$ by a reduction in IL-2 production [112]. T cells treated directly with calcitriol or its analogues had decreased expression (in the absence of antigen-presenting cells) of Th1 (IL-2, TNF- $\alpha$, IFN- $\gamma$ ), Th9 (IL-9) and Th22 (IL-22) cytokines [97,117,118], but increased production of anti-inflammatory Th2 cytokines (IL-3, IL-4, IL-5, IL-10) [119]. While the immunosuppressive effects of vitamin D on Th1 cells are clear, the effects of vitamin D on Th2 cytokine expression are contradictory and yet to be clarified. Some studies showed that $1,25(\mathrm{OH})_{2} \mathrm{D}_{3}$ favours Th2 cells by upregulating the expression of Th2-specific transcription factors GATA-3 and c-Maf, as well as IL-4 in mice [119,120]. Others contradicted these findings, with c-Maf being undetectable in the presence of vitamin D [121] and decreased Th2 cytokine levels [112,122]. Apart from T cells, evidence suggest that IgE production by $\mathrm{B}$ cells is also suppressed by $1,25(\mathrm{OH})_{2} \mathrm{D}_{3}[123]$.

\section{The Role of Vitamin D Status in Failed Oral Tolerance and Development of Food Allergy}

IgE-mediated food allergy, the most common form of food allergy [124], usually develops in the first year of life, presumably as a result of aberrant immune development. Food allergy is generally Th2-biased and is characterised by the secretion of IL-4, IL-5, IL-9 and IL-13 and allergen-specific IgE antibody [125,126]. Early IgE production to food allergens (sensitization) occurs through oral and gut mucosal or cutaneous food exposures [126-128]. Allergen-specific IgE antibodies bind to high-affinity $\mathrm{Fc} \varepsilon$ receptors ( $\mathrm{Fc} \varepsilon \mathrm{RI}$ ) on the surface of mast cells and basophils upon re-exposure to the food constituents [129]. This triggers degranulation of mast cells and basophils, releasing the preformed mediators, histamine, tryptase and TNFs, which promote oedema, erythema and itch [124,126,130]. Newly-synthesized mediators, such as leukotrienes (e.g., LTC4), prostaglandins (e.g., PGD $_{2}$ ) and cytokines (e.g., IL-3, IL-5), lead to the recruitment of inflammatory cells responsible for IgE-mediated late-phase responses [124,131]. Class-switching to pro-allergic IgE antibody production is promoted by $\mathrm{T}$ cell production of IL-4 and IL-13 [132]. While sensitization predisposes individuals to food allergy, they may not develop the clinical manifestations mentioned above [133]. Currently, it is not well understood why certain individuals do not develop food allergy despite producing IgE antibodies. 
Controversy remains regarding the role of vitamin $\mathrm{D}$ in the development of food allergy. On the one hand, some research suggests that vitamin D insufficiency increases the risk of IgE-mediated food allergy [7] and food sensitization [134]. By contrast, vitamin D excess in pregnancy and at birth has also been associated with an increased risk of food allergy [135]. It is thought that the lower number of Tregs associated with high cord blood vitamin D may compromise immune tolerance, since a low Treg count has been previously found to predict the development of early atopic dermatitis [136]. The contribution of vitamin D in allergic diseases is evident in mouse studies [137,138]. Production of thymic stromal lymphopoietin (TSLP) in keratinocytes is essential in promoting allergic sensitization through an impaired skin barrier and eventual development of allergic asthma [137]. The application of vitamin D or an analogue induces TSLP transcription by enhancing its promoter activity [138]. Although a unifying hypothesis for the role of vitamin D in food allergy development would suggest a U-shaped relationship [10,139], the evidence remains thin and as yet to be validated by randomized controlled trials.

Evidence for the role of low vitamin D in food allergy development is currently the strongest. Vassallo et al. [140] proposed a "multiple-hit model" where low vitamin D results in an increased susceptibility to gastrointestinal infections and compromised barrier defences. In the presence of an altered microbial ecology of the gastrointestinal tract and a lowered immune tolerance, this may predispose an individual to allergic responses to food antigens. This is supported by emerging research showing the effects of $1,25(\mathrm{OH})_{2} \mathrm{D}_{3}$ to promote mucosal barrier function [141], inhibit pro-allergic immune responses and promote immunologic tolerance [14]. In maintaining mucosal barrier function, $1,25(\mathrm{OH})_{2} \mathrm{D}_{3}$ enhances the expression of genes encoding proteins required for epithelial tight junctions (e.g., occludin), gap junctions (e.g., connexion 43) and adherens junctions (e.g., E-cadherin) [142-145].

The vitamin D mechanisms contributing to immune tolerance include the induction of tolerogenic DCs [146] and Tregs [14] and inhibition of IgE production in B cells [147]. Repeated exposures to low doses of food antigen have been found to be optimal for the development of Tregs [108], for oral tolerance. This may in part be established by mucosal tolerogenic DCs to induce Tregs in the mesenteric lymph nodes [148]. Mice studies showed that Tregs were able to alleviate clinical signs of immediate-type hypersensitivity reactions in IgE-mediated food allergy [149,150]. Studies in human subjects have also shown that DCs of allergic patients are less responsive to Th1-inducing stimuli, hence increasing susceptibility to a Th2-skewed profile [151].

Suppression of IgE production is also modulated by anti-CD40 antibody- and IL-4-stimulated B cells exposed to the vitamin D analogue, EB1089 [152], and this finding was replicated in vivo in an allergy mouse model [153]. Human B cell experiments have also shown that $1,25(\mathrm{OH})_{2} \mathrm{D}_{3}$ suppresses IgE antibody class switch partly through inhibition of NF- $\mathrm{KB}$ and epsilon germ-line transcription ( $\varepsilon$ GLT) [152]. IL-10 production is however inhibited in anti-CD40/IL-4-activated B cells, either directly, through binding of VDR to the promoter region of IL-10, and/or indirectly by the modulation of calcium [147].

Some epidemiological evidence suggests that vitamin D excess may also contribute to food allergy pathogenesis. The relationship between $25(\mathrm{OH}) \mathrm{D}$ concentrations and allergy may not be linear, with one study proposing a U-shaped association between vitamin $\mathrm{D}_{3}$ with total serum $\operatorname{IgE}$ concentration production in adults [10]. In this study, elevated IgE levels were observed in both groups of 
participants with the lowest $(<25 \mathrm{nmol} / \mathrm{L})$ and highest $(>135 \mathrm{nmol} / \mathrm{L})$ concentrations of serum $25(\mathrm{OH}) \mathrm{D}_{3}$. This dual effect of vitamin $\mathrm{D}$ is supported by mouse data, which showed that while $1,25(\mathrm{OH})_{2} \mathrm{D}_{3}$ downregulates airway eosinophilia through reduction in inflammation, it also enhances allergen-specific T cell activation, systemic IgE levels and IL-4 and IL-13 secretion [154].

Similarly, cord blood concentrations of $25(\mathrm{OH}) \mathrm{D}$ also had a U-shaped association with aeroallergen-specific IgE, with an odds ratio of 2.4 and four for low and high concentrations of $25(\mathrm{OH}) \mathrm{D}$, respectively [155]. In measuring cord blood $25(\mathrm{OH}) \mathrm{D}_{3}$, a recent study suggested a strong correlation between maternal vitamin D level and cord blood levels of neonates [156], and this is dependent on the ability of $25(\mathrm{OH}) \mathrm{D}_{3}$ to cross the placenta [157]. As such, the role of maternal vitamin D status and vitamin D immunoregulation in utero also warrants further investigation.

\section{Conclusions}

There is significant interest in the role of vitamin D for optimal immune health. Recent epidemiological evidence suggests that both insufficiency and excess of vitamin D may contribute to the failure of oral tolerance and subsequent food allergy in infants. It is evident that vitamin D has wide-ranging effects on the immune system, but how it modulates immune function in food allergy is not clear. While food allergy is often characterised as a Th2-skewed immune response, this is likely to be an oversimplification. The mechanisms underlying innate and adaptive immune dysfunction in food allergy require deeper investigations. At the clinical level, questions about the efficacy and safety of vitamin $\mathrm{D}$ in preventing food allergy will only be answered by randomized controlled trials.

\section{Acknowledgments}

N.H.A.S. is a holder of the Centre for Food \& Allergy Research Postgraduate Scholarship.

\section{Author Contributions}

N.H.A.S. drafted the initial manuscript. The remaining authors critically reviewed and proof read the manuscript. All authors approved the final manuscript as submitted.

\section{Conflicts of Interest}

K.J.A. has received speaker's honorariums from Nutricia, Danone, Nestle, Alphapharm and Aspen. The other authors declare no conflict of interest.

\section{References}

1. Provvedini, D.; Tsoukas, C.; Deftos, L.; Manolagas, S. 1,25-dihydroxyvitamin D3 receptors in human leukocytes. Science 1983, 221, 1181-1183. [CrossRef] [PubMed]

2. Bhalla, A.K.; Amento, E.P.; Clemens, T.L.; Holick, M.F.; Krane, S.M. Specific high-affinity receptors for 1,25-dihydroxyvitamin D3 in human peripheral blood mononuclear cells: Presence in monocytes and induction in T lymphocytes following activation. J. Clin. Endocrinol. Metab. 1983, 57, 1308-1310. [CrossRef] [PubMed] 
3. Camargo, C.A.; Rifas-Shiman, S.L.; Litonjua, A.A.; Rich-Edwards, J.W.; Weiss, S.T.; Gold, D.R.; Kleinman, K.; Gillman, M.W. Maternal intake of vitamin D during pregnancy and risk of recurrent wheeze in children at 3 y of age. Am. J. Clin. Nutr. 2007, 85, 788-795. [PubMed]

4. Black, P.N.; Scragg, R. Relationship between serum 25-hydroxyvitamin D and pulmonary function in the third national health and nutrition examination survey. Chest 2005, 128, 3792-3798. [CrossRef] [PubMed]

5. Adorini, L.; Penna, G. Control of autoimmune diseases by the vitamin D endocrine system. Nat. Clin. Pract. Rheumatol. 2008, 4, 404-412. [CrossRef] [PubMed]

6. Van der Mei, I.A.; Ponsonby, A.L.; Dwyer, T.; Blizzard, L.; Simmons, R.; Taylor, B.V.; Butzkueven, H.; Kilpatrick, T. Past exposure to sun, skin phenotype, and risk of multiple sclerosis: Case-control study. BMJ 2003, 327, 316. [CrossRef] [PubMed]

7. Allen, K.J.; Koplin, J.J.; Ponsonby, A.L.; Gurrin, L.C.; Wake, M.; Vuillermin, P.; Martin, P.; Matheson, M.; Lowe, A.; Robinson, M.; et al. Vitamin D insufficiency is associated with challenge-proven food allergy in infants. J. Allergy Clin. Immunol. 2013, 131, 1109-1116.e6. [CrossRef] [PubMed]

8. Mullins, R.J.; Camargo, C.A. Latitude, sunlight, vitamin D, and childhood food allergy/anaphylaxis. Curr. Allergy Asthma Rep. 2012, 12, 64-71. [CrossRef] [PubMed]

9. Osborne, N.J.; Ukoumunne, O.C.; Wake, M.; Allen, K.J. Prevalence of eczema and food allergy is associated with latitude in Australia. J. Allergy Clin. Immunol. 2012, 129, 865-867. [CrossRef] [PubMed]

10. Hyppönen, E.; Berry, D.J.; Wjst, M.; Power, C. Serum 25-hydroxyvitamin D and IgE-A significant but nonlinear relationship. Allergy 2009, 64, 613-620. [CrossRef] [PubMed]

11. Peroni, D.G.; Boner, A.L. Food allergy: The perspectives of prevention using vitamin D. Curr. Opin. Allergy Clin. Immunol. 2013, 13, 287-292. [CrossRef] [PubMed]

12. Baeke, F.; Takiishi, T.; Korf, H.; Gysemans, C.; Mathieu, C. Vitamin D: Modulator of the immune system. Curr. Opin. Pharmacol. 2010, 10, 482-496. [CrossRef] [PubMed]

13. White, J.H. Vitamin D signaling, infectious diseases, and regulation of innate immunity. Infect. Immun. 2008, 76, 3837-3843. [CrossRef] [PubMed]

14. Dimeloe, S.; Nanzer, A.; Ryanna, K.; Hawrylowicz, C. Regulatory T cells, inflammation and the allergic response-the role of glucocorticoids and vitamin D. J. Steroid Biochem. Mol. Biol. 2010, 120, 86-95. [CrossRef] [PubMed]

15. Trinchieri, G.; Sher, A. Cooperation of toll-like receptor signals in innate immune defence. Nat. Rev. Immunol. 2007, 7, 179-190. [CrossRef] [PubMed]

16. Institute of Medicine (US) Standing Committee on the Scientific Evaluation of Dietary Reference Intakes. Vitamin D. In Dietary Reference Intakes for Calcium, Phosphorus, Magnesium, Vitamin D and Fluoride; National Academies Press (US): Washington, DC, USA, 1997.

17. Working Group of the Australian and New Zealand Bone and Mineral Society; Endocrine Society of Australia and Osteoporosis Australia. Vitamin D and adult bone health in Australia and New Zealand: A position statement. Med. J. Aust. 2005, 182, 281-285. 
18. Holick, M.F.; Frommer, J.E.; McNeill, S.C.; Richtand, N.M.; Henley, J.W.; Potts, J.T. Photometabolism of 7-dehydrocholesterol to previtamin D3 in skin. Biochem. Biophys. Res. Commun. 1977, 76, 107-114. [CrossRef]

19. Horst, R.; Reinhardt, T.; Reddy, S. Vitamin D metabolism. In Vitamin D; Feldman, D., Pike, J., Glorieux, F., Eds.; Elsevier Academic Press: London, UK, 2005; pp. 15-36.

20. Hollis, B.W. Comparison of equilibrium and disequilibrium assay conditions for ergocalciferol, cholecalciferol and their major metabolites. J. Steroid Biochem. 1984, 21, 81-86. [CrossRef]

21. Houghton, L.A.; Vieth, R. The case against ergocalciferol (vitamin D2) as a vitamin supplement. Am. J. Clin. Nutr. 2006, 84, 694-697. [PubMed]

22. Armas, L.A.; Hollis, B.W.; Heaney, R.P. Vitamin D2 is much less effective than vitamin D3 in humans. J. Clin. Endocrinol. Metab. 2004, 89, 5387-5391. [CrossRef] [PubMed]

23. Trang, H.M.; Cole, D.E.; Rubin, L.A.; Pierratos, A.; Siu, S.; Vieth, R. Evidence that vitamin D3 increases serum 25-hydroxyvitamin D more efficiently than does vitamin D2. Am. J. Clin. Nutr. 1998, 68, 854-858. [PubMed]

24. Cheng, J.B.; Motola, D.L.; Mangelsdorf, D.J.; Russell, D.W. De-Orphanization of cytochrome P450 2R1: A microsomal vitamin D 25-hydroxilase. J. Biol. Chem. 2003, 278, 38084-38093. [CrossRef] [PubMed]

25. Gupta, R.P.; He, Y.A.; Patrick, K.S.; Halpert, J.R.; Bell, N.H. CYP3A4 is a vitamin D-24- and 25-hydroxylase: Analysis of structure function by site-directed mutagenesis. J. Clin. Endocrinol. Metab. 2005, 90, 1210-1219. [CrossRef] [PubMed]

26. Gupta, R.P.; Hollis, B.W.; Patel, S.B.; Patrick, K.S.; Bell, N.H. CYP3A4 is a human microsomal vitamin D 25-hydroxylase. J. Bone Miner. Res. 2004, 19, 680-688. [CrossRef] [PubMed]

27. Wang, Z.; Schuetz, E.G.; Xu, Y.; Thummel, K.E. Interplay between vitamin D and the drug metabolizing enzyme CYP3A4. J. Steroid Biochem. Mol. Biol. 2013, 136, 54-58. [CrossRef] [PubMed]

28. Zhu, J.; DeLuca, H.F. Vitamin D 25-hydroxylase-Four decades of searching, are we there yet? Arch. Biochem. Biophys. 2012, 523, 30-36. [CrossRef] [PubMed]

29. Bikle, D.D.; Gee, E.; Halloran, B.; Kowalski, M.A.; Ryzen, E.; Haddad, J.G. Assessment of the free fraction of 25-hydroxyvitamin $\mathrm{D}$ in serum and its regulation by albumin and the vitamin D-binding protein. J. Clin. Endocrinol. Metab. 1986, 63, 954-959. [CrossRef] [PubMed]

30. Tang, J.Y.; Fu, T.; Lau, C.; Oh, D.H.; Bikle, D.D.; Asgari, M.M. Vitamin D in cutaneous carcinogenesis: Part I. J. Am. Acad. Dermatol. 2012, 67, 803.e1-803.e12. [CrossRef] [PubMed]

31. Guessous, I. Role of vitamin D deficiency in extraskeletal complications: Predictor of health outcome or marker of health status? Biomed. Res. Int. 2015, 2015, 13. [CrossRef] [PubMed]

32. Bossé, Y.; Lemire, M.; Poon, A.H.; Daley, D.; He, J.-Q.; Sandford, A.; White, J.H.; James, A.L.; Musk, A.W.; Palmer, L.J.; et al. Asthma and genes encoding components of the vitamin D pathway. Respir. Res. 2009, 10, 98-118. [CrossRef] [PubMed]

33. Zella, L.A.; Shevde, N.K.; Hollis, B.W.; Cooke, N.E.; Pike, J.W. Vitamin D-binding protein influences total circulating levels of 1,25-dihydroxyvitamin $\mathrm{D}(3)$ but does not directly modulate the bioactive levels of the hormone in vivo. Endocrinology 2008, 149, 3656-3667. [CrossRef] [PubMed] 
34. Bikle, D.D.; Gee, E. Free, and not total, 1,25-dihydroxyvitamin D regulates 25-hydroxyvitamin D metabolism by keratinocytes. Endocrinology 1989, 124, 649-654. [CrossRef] [PubMed]

35. Schlingmann, K.P.; Kaufmann, M.; Weber, S.; Irwin, A.; Goos, C.; John, U.; Misselwitz, J.; Klaus, G.; Kuwertz-Broking, E.; Fehrenbach, H.; et al. Mutations in CYP24A1 and idiopathic infantile hypercalcemia. N. Engl. J. Med. 2011, 365, 410-421. [CrossRef] [PubMed]

36. Jones, G.; Prosser, D.E.; Kaufmann, M. 25-hydroxyvitamin D-24-hydroxylase (CYP24A1): Its important role in the degradation of vitamin D. Arch. Biochem. Biophys. 2012, 523, 9-18. [CrossRef] [PubMed]

37. Gombart, A.F. The vitamin D-antimicrobial peptide pathway and its role in protection against infection. Future Microbiol. 2009, 4, 1151-1165. [CrossRef] [PubMed]

38. Henry, H.L. Regulation of vitamin D metabolism. Best Pract. Res. Clin. Endocrinol. Metab. 2011, 25, 531-541. [CrossRef] [PubMed]

39. Bergwitz, C.; Jüppner, H. Regulation of phosphate homeostasis by PTH, vitamin D, and FGF23. Annu. Rev. Med. 2010, 61, 91-104. [CrossRef] [PubMed]

40. Galitzer, H.; Ben-Dov, I.; Lavi-Moshayoff, V.; Naveh-Many, T.; Silver, J. Fibroblast growth factor 23 acts on the parathyroid to decrease parathyroid hormone secretion. Curr. Opin. Nephrol. Hypertens. 2008, 17, 363-367. [CrossRef] [PubMed]

41. Pike, J.W.; Meyer, M.B.; Bishop, K.A. Regulation of target gene expression by the vitamin D receptor-An update on mechanisms. Rev. Endocr. Metab. Disord. 2012, 13, 45-55. [CrossRef] [PubMed]

42. Prietl, B.; Treiber, G.; Pieber, T.R.; Amrein, K. Vitamin D and immune function. Nutrients 2013, 5, 2502-2521. [CrossRef] [PubMed]

43. Sigmundsdottir, H.; Pan, J.; Debes, G.F.; Alt, C.; Habtezion, A.; Soler, D.; Butcher, E.C. DCs metabolize sunlight-induced vitamin D3 to "program" T cell attraction to the epidermal chemokine CCL27. Nat. Immunol. 2007, 8, 285-293. [CrossRef] [PubMed]

44. Gottfried, E.; Rehli, M.; Hahn, J.; Holler, E.; Andreesen, R.; Kreutz, M. Monocyte-Derived cells express CYP27A1 and convert vitamin D3 into its active metabolite. Biochem. Biophys. Res. Commun. 2006, 349, 209-213. [CrossRef] [PubMed]

45. Stoffels, K.; Overbergh, L.; Giulietti, A.; Verlinden, L.; Bouillon, R.; Mathieu, C. Immune regulation of 25-hydroxyvitamin-D3-1alpha-hydroxylase in human monocytes. J. Bone Miner. Res. 2006, 21, 37-47. [CrossRef] [PubMed]

46. Overbergh, L.; Decallonne, B.; Valckx, D.; Verstuyf, A.; Depovere, J.; Laureys, J.; Rutgeerts, O.; Saint-Arnaud, R.; Bouillon, R.; Mathieu, C. Identification and immune regulation of 25-hydroxyvitamin D-1- $\alpha$-hydroxylase in murine macrophages. Clin. Exp. Immunol. 2000, 120, 139-146. [CrossRef] [PubMed]

47. Liu, P.T.; Stenger, S.; Li, H.; Wenzel, L.; Tan, B.H.; Krutzik, S.R.; Ochoa, M.T.; Schauber, J.; Wu, K.; Meinken, C.; et al. Toll-like receptor triggering of a vitamin D-mediated human antimicrobial response. Science 2006, 311, 1770-1773. [CrossRef] [PubMed]

48. Bikle, D. Nonclassic actions of vitamin D. J. Clin. Endocrinol. Metab. 2009, 94, $26-34$. [CrossRef] [PubMed] 
49. Ren, S.; Nguyen, L.; Wu, S.; Encinas, C.; Adams, J.S.; Hewison, M. Alternative splicing of vitamin D-24-hydroxylase: A novel mechanism for the regulation of extrarenal 1,25-dihydroxyvitamin D synthesis. J. Biol. Chem. 2005, 280, 20604-20611. [CrossRef] [PubMed]

50. Adams, J.S.; Singer, F.R.; Gacad, M.A.; Sharma, O.P.; Hayes, M.J.; Vouros, P.; Holick, M.F. Isolation and structural identification of 1,25-dihydroxyvitamin D3 produced by cultured alveolar macrophages in sarcoidosis. J. Clin. Endocrinol. Metab. 1985, 60, 960-966. [CrossRef] [PubMed]

51. Tucker, G., III; Gagnon, R.E.; Haussler, M.R. Vitamin D3-25-hydroxylase: Tissue occurrence and apparent lack of regulation. Arch. Biochem. Biophys. 1973, 155, 47-57. [CrossRef]

52. Ichikawa, F.; Sato, K.; Nanjo, M.; Nishii, Y.; Shinki, T.; Takahashi, N.; Suda, T. Mouse primary osteoblasts express vitamin D3 25-hydroxylase mRNA and convert 1 alpha-hydroxyvitamin D3 into 1 alpha,25-dihydroxyvitamin D3. Bone 1995, 16, 129-135. [CrossRef]

53. Shiga, K.; Fukuyama, R.; Kimura, S.; Nakajima, K.; Fushiki, S. Mutation of the sterol 27-hydroxylase gene (CYP27) results in truncation of mRNA expressed in leucocytes in a Japanese family with cerebrotendinous xanthomatosis. J. Neurol. Neurosurg. Psychiatry 1999, 67, 675-677. [CrossRef] [PubMed]

54. Hewison, M.; Zehnder, D.; Bland, R.; Stewart, P. 1alpha-hydroxylase and the action of vitamin D. J. Mol. Endocrinol. 2000, 25, 141-148. [CrossRef] [PubMed]

55. Karlgren, M.; Miura, S.; Ingelman-Sundberg, M. Novel extrahepatic cytochrome P450s. Toxicol. Appl. Pharmacol. 2005, 207, 57-61. [CrossRef] [PubMed]

56. McKenna, N.J.; O’Malley, B.W. Combinatorial control of gene expression by nuclear receptors and coregulators. Cell 2002, 108, 465-474. [CrossRef]

57. Meyer, M.B.; Pike, J.W. Corepressors (NCOR and SMRT) as well as coactivators are recruited to positively regulated 1alpha,25-dihydroxyvitamin D3-responsive genes. J. Steroid Biochem. Mol. Biol. 2013, 136, 120-124. [CrossRef] [PubMed]

58. Hsieh, J.C.; Jurutka, P.W.; Nakajima, S.; Galligan, M.A.; Haussler, C.A.; Shimizu, Y.; Shimizu, N.; Whitfield, G.K.; Haussler, M.R. Phosphorylation of the human vitamin D receptor by protein kinase C. Biochemical and functional evaluation of the serine 51 recognition site. J. Biol. Chem. 1993, 268, 15118-15126. [PubMed]

59. Pike, J.W.; Sleator, N.M. Hormone-Dependent phosphorylation of the 1,25-dihydroxyvitamin D3 receptor in mouse fibroblasts. Biochem. Biophys. Res. Commun. 1985, 131, 378-385. [CrossRef]

60. Norman, A.W.; Okamura, W.H.; Hammond, M.W.; Bishop, J.E.; Dormanen, M.C.; Bouillon, R.; Van Baelen, H.; Ridall, A.L.; Daane, E.; Khoury, R.; et al. Comparison of 6-s-cis- and 6 -s-trans-locked analogs of $1 \alpha, 25$-dihydroxyvitamin D3 indicates that the 6-s-cis conformation is preferred for rapid nongenomic biological responses and that neither 6-s-cis- nor 6-s- trans-locked analogs are preferred for genomic biological responses. Mol. Endocrinol. 1997, 11, 1518-1531. [PubMed]

61. Huhtakangas, J.A.; Olivera, C.J.; Bishop, J.E.; Zanello, L.P.; Norman, A.W. The vitamin D receptor is present in caveolae-enriched plasma membranes and binds $1 \alpha, 25(\mathrm{OH}) 2$-vitamin D3 in vivo and in vitro. Mol. Endocrinol. 2004, 18, 2660-2671. [CrossRef] [PubMed] 
62. Zanello, L.P.; Norman, A.W. Rapid modulation of osteoblast ion channel responses by $1 \alpha, 25(\mathrm{OH}) 2$-vitamin D3 requires the presence of a functional vitamin D nuclear receptor. Proc. Natl. Acad. Sci. USA 2004, 101, 1589-1594. [CrossRef] [PubMed]

63. Sylvia, V.L.; Schwartz, Z.; Schuman, L.; Morgan, R.T.; Mackey, S.; Gomez, R.; Boyan, B.D. Maturation-dependent regulation of protein kinase $\mathrm{C}$ activity by vitamin D3 metabolites in chondrocyte cultures. J. Cell. Physiol. 1993, 157, 271-278. [CrossRef] [PubMed]

64. De Boland, A.R.; Nemere, I. Rapid actions of vitamin D compounds. J. Cell. Biochem. 1992, 49, 32-36. [CrossRef] [PubMed]

65. Slater, S.J.; Kelly, M.B.; Taddeo, F.J.; Larkin, J.D.; Yeager, M.D.; McLane, J.A.; Ho, C.; Stubbs, C.D. Direct activation of protein kinase C by $1 \alpha, 25$-dihydroxyvitamin D3. J. Biol. Chem. 1995, 270, 6639-6643. [PubMed]

66. Nutchey, B.K.; Kaplan, J.S.; Dwivedi, P.P.; Omdahl, J.L.; Ferrante, A.; May, B.K.; Hii, C.S. Molecular action of 1,25-dihydroxyvitamin D3 and phorbol ester on the activation of the rat cytochrome P450C24 (CYP24) promoter: Role of MAP kinase activities and identification of an important transcription factor binding site. Biochem. J. 2005, 389, 753-762. [PubMed]

67. Dwivedi, P.P.; Gao, X.-H.; Tan, J.C.-T.; Evdokiou, A.; Ferrante, A.; Morris, H.A.; May, B.K.; Hii, C.S.T. A role for the phosphatidylinositol 3-kinase-Protein kinase C zeta—sp1 pathway in the 1,25-dihydroxyvitamin D3 induction of the 25-hydroxyvitamin D3 24-hydroxylase gene in human kidney cells. Cell Signal. 2010, 22, 543-552. [CrossRef] [PubMed]

68. Dwivedi, P.P.; Hii, C.S.; Ferrante, A.; Tan, J.; Der, C.J.; Omdahl, J.L.; Morris, H.A.; May, B.K. Role of MAP kinases in the 1,25-dihydroxyvitamin D3-induced transactivation of the rat cytochrome P450C24 (CYP24) promoter. Specific functions for ERK1/ERK2 and ERK5. J. Biol. Chem. 2002, 277, 29643-29653. [CrossRef] [PubMed]

69. St-Arnaud, R. Targeted inactivation of vitamin D hydroxylases in mice. Bone 1999, 25, 127-129. [CrossRef]

70. St-Arnaud, R.; Arabian, A.; Travers, R.; Barletta, F.; Raval-Pandya, M.; Chapin, K.; Depovere, J.; Mathieu, C.; Christakos, S.; Demay, M.B.; et al. Deficient mineralization of intramembranous bone in vitamin D-24-hydroxylase-ablated mice is due to elevated 1,25-dihydroxyvitamin D and not to the absence of 24,25-dihydroxyvitamin D. Endocrinology 2000, 141, 2658-2666. [CrossRef] [PubMed]

71. Masuda, S.; Kaufmann, M.; Byford, V.; Gao, M.; St-Arnaud, R.; Arabian, A.; Makin, H.L.J.; Knutson, J.C.; Strugnell, S.; Jones, G. Insights into vitamin D metabolism using CYP24 over-expression and knockout systems in conjunction with liquid chromatography/mass spectrometry (LC/MS). J. Steroid Biochem. Mol. Biol. 2004, 89-90, 149-153. [CrossRef] [PubMed]

72. Jones, G. Pharmacokinetics of vitamin D toxicity. Am. J. Clin. Nutr. 2008, 88, 582S-586S. [PubMed] 
73. Nowson, C.A.; McGrath, J.J.; Ebeling, P.R.; Haikerwal, A.; Daly, R.M.; Sanders, K.M.; Seibel, M.J.; Mason, R.S. Vitamin D and health in adults in Australia and New Zealand: A position statement. Med. J. Aust. 2012, 196, 686-687. [CrossRef] [PubMed]

74. Institute of Medicine Committee to Review Dietary Reference Intakes for vitamin D and Calcium. The national academies collection: Reports funded by National Institutes of Health. In Dietary Reference Intakes for Calcium and Vitamin D; Ross, A.C., Taylor, C.L., Yaktine, A.L., Del Valle, H.B., Eds.; National Academies Press (US), National Academy of Sciences: Washington, DC, USA, 2011.

75. Devine, A.; Wilson, S.G.; Dick, I.M.; Prince, R.L. Effects of vitamin D metabolites on intestinal calcium absorption and bone turnover in elderly women. Am. J. Clin. Nutr. 2002, 75, 283-288. [PubMed]

76. Nordin, B.E.C.; Need, A.G. The relation between serum calcidiol and calcitriol. IBMS BoneKEy 2005, 2, 7-16. [CrossRef]

77. Elkassaby, S.; Harrison, L.C.; Mazzitelli, N.; Wentworth, J.M.; Colman, P.G.; Spelman, T.; Fourlanos, S. A randomised controlled trial of high dose vitamin D in recent-onset type 2 diabetes. Diabetes Res. Clin. Pract. 2014, 106, 576-582. [CrossRef] [PubMed]

78. Vieth, R.; Ladak, Y.; Walfish, P.G. Age-related changes in the 25-hydroxyvitamin D versus parathyroid hormone relationship suggest a different reason why older adults require more vitamin D. J. Clin. Endocrinol. Metab. 2003, 88, 185-191. [CrossRef] [PubMed]

79. Tjellesen, L.; Christiansen, C. Vitamin D metabolites in normal subjects during one year. A longitudinal study. Scand. J. Clin. Lab. Investig. 1983, 43, 85-89. [CrossRef]

80. Medzhitov, R. Recognition of microorganisms and activation of the immune response. Nature 2007, 449, 819-826. [CrossRef] [PubMed]

81. Hoxha, M.; Zoto, M.; Deda, L.; Vyshka, G. Vitamin D and its role as a protective factor in allergy. Int. Sch. Res. Not. 2014, 2014, 7. [CrossRef]

82. Muehleisen, B.; Gallo, R.L. Vitamin D in allergic disease: Shedding light on a complex problem. J. Allergy Clin. Immunol. 2013, 131, 324-329. [CrossRef] [PubMed]

83. Adams, J.S.; Hewison, M. Unexpected actions of vitamin D: New perspectives on the regulation of innate and adaptive immunity. Nat. Clin. Pract. Endocrinol. Metab. 2008, 4, 80-90. [CrossRef] [PubMed]

84. Sadeghi, K.; Wessner, B.; Laggner, U.; Ploder, M.; Tamandl, D.; Friedl, J.; Zügel, U.; Steinmeyer, A.; Pollak, A.; Roth, E. Vitamin D3 down-regulates monocyte TLR expression and triggers hyporesponsiveness to pathogen-associated molecular patterns. Eur. J. Immunol. 2006, 36, 361-370. [CrossRef] [PubMed]

85. Wang, T.T.; Nestel, F.P.; Bourdeau, V.; Nagai, Y.; Wang, Q.; Liao, J.; Tavera-Mendoza, L.; Lin, R.; Hanrahan, J.W.; Mader, S.; et al. Cutting edge: 1,25-dihydroxyvitamin D3 is a direct inducer of antimicrobial peptide gene expression. J. Immunol. 2004, 173, 2909-2912. [CrossRef] [PubMed] 
86. Buchau, A.S.; Morizane, S.; Trowbridge, J.; Schauber, J.; Kotol, P.; Bui, J.D.; Gallo, R.L. The host defense peptide cathelicidin is required for NK cell-mediated suppression of tumor growth. J. Immunol. 2010, 184, 369-378. [CrossRef] [PubMed]

87. Fabri, M.; Stenger, S.; Shin, D.-M.; Yuk, J.-M.; Liu, P.T.; Realegeno, S.; Lee, H.-M.; Krutzik, S.R.; Schenk, M.; Sieling, P.A.; et al. Vitamin D is required for IFN- $\gamma-$ mediated antimicrobial activity of human macrophages. Sci. Transl. Med. 2011, 3, 104ra102-104ra102. [CrossRef] [PubMed]

88. Yuk, J.-M.; Shin, D.-M.; Lee, H.-M.; Yang, C.-S.; Jin, H.S.; Kim, K.-K.; Lee, Z.-W.; Lee, S.-H.; Kim, J.-M.; Jo, E.-K. Vitamin D3 induces autophagy in human monocytes/macrophages via cathelicidin. Cell Host Microbe 2009, 6, 231-243. [CrossRef] [PubMed]

89. Weinberg, J.B. Nitric oxide production and nitric oxide synthase type 2 expression by human mononuclear phagocytes: A review. Mol. Med. 1998, 4, 557-591. [PubMed]

90. Denis, M. Human monocytes/macrophages: NO or no NO? J. Leukoc. Biol. 1994, 55, 682-684. [PubMed]

91. Kamen, D.L.; Tangpricha, V. Vitamin D and molecular actions on the immune system: Modulation of innate and autoimmunity. J. Mol. Med. (Berl.) 2010, 88, 441-450. [CrossRef] [PubMed]

92. Lim, W.C.; Hanauer, S.B.; Li, Y.C. Mechanisms of disease: Vitamin D and inflammatory bowel disease. Nat. Clin. Pract. Gastroenterol. Hepatol. 2005, 2, 308-315. [CrossRef] [PubMed]

93. Almerighi, C.; Sinistro, A.; Cavazza, A.; Ciaprini, C.; Rocchi, G.; Bergamini, A. 1alpha,25-dihydroxyvitamin D3 inhibits CD401-induced pro-inflammatory and immunomodulatory activity in human monocytes. Cytokine 2009, 45, 190-197. [CrossRef] [PubMed]

94. Penna, G.; Adorini, L. 1 $\propto, 25$-dihydroxyvitamin D3 inhibits differentiation, maturation, activation, and survival of dendritic cells leading to impaired alloreactive T cell activation. J. Immunol. 2000, 164, 2405-2411. [CrossRef] [PubMed]

95. Griffin, M.D.; Lutz, W.; Phan, V.A.; Bachman, L.A.; McKean, D.J.; Kumar, R. Dendritic cell modulation by 1alpha,25 dihydroxyvitamin D3 and its analogs: A vitamin D receptor-dependent pathway that promotes a persistent state of immaturity in vitro and in vivo. Proc. Natl. Acad. Sci. USA 2001, 98, 6800-6805. [CrossRef] [PubMed]

96. Xu, H.; Soruri, A.; Gieseler, R.K.H.; Peters, J.H. 1,25-dihydroxyvitamin D3 exerts opposing effects to IL-4 on MHC class-II antigen expression, accessory activity, and phagocytosis of human monocytes. Scand. J. Immunol. 1993, 38, 535-540. [CrossRef] [PubMed]

97. Lemire, J.M.; Archer, D.C.; Beck, L.; Spiegelberg, H.L. Immunosuppressive actions of 1,25-dihydroxyvitamin D3: Preferential inhibition of TH1 functions. J. Nutr. 1995, 125, 1704s-1708s. [PubMed] 
98. D’Ambrosio, D.; Cippitelli, M.; Cocciolo, M.G.; Mazzeo, D.; Di Lucia, P.; Lang, R.; Sinigaglia, F.; Panina-Bordignon, P. Inhibition of IL-12 production by 1,25-dihydroxyvitamin D3. Involvement of NF-kappaB downregulation in transcriptional repression of the P40 gene. J. Clin. Investig. 1998, 101, 252-262. [CrossRef] [PubMed]

99. Etten, E.V.; Mathieu, C. Immunoregulation by 1,25-dihydroxyvitamin D3: Basic concepts. J. Steroid Biochem. Mol. Biol. 2005, 97, 93-101. [CrossRef] [PubMed]

100. Penna, G.; Roncari, A.; Amuchastegui, S.; Daniel, K.C.; Berti, E.; Colonna, M.; Adorini, L. Expression of the inhibitory receptor ILT3 on dendritic cells is dispensable for induction of CD4+FOXP3+ regulatory T cells by 1,25-dihydroxyvitamin D3. Blood 2005, 106, 3490-3497. [CrossRef] [PubMed]

101. Biggs, L.; Yu, C.; Fedoric, B.; Lopez, A.F.; Galli, S.J.; Grimbaldeston, M.A. Evidence that vitamin D3 promotes mast cell-dependent reduction of chronic UVB-induced skin pathology in mice. J. Exp. Med. 2010, 207, 455-463. [CrossRef] [PubMed]

102. Yip, K.H.; Kolesnikoff, N.; Yu, C.; Hauschild, N.; Taing, H.; Biggs, L.; Goltzman, D.; Gregory, P.A.; Anderson, P.H.; Samuel, M.S.; et al. Mechanisms of vitamin D(3) metabolite repression of IgE-dependent mast cell activation. J. Allergy Clin. Immunol. 2014, 133, 1356-1364.e14. [CrossRef] [PubMed]

103. Coussens, A.K.; Wilkinson, R.J.; Hanifa, Y.; Nikolayevskyy, V.; Elkington, P.T.; Islam, K.; Timms, P.M.; Venton, T.R.; Bothamley, G.H.; Packe, G.E.; et al. Vitamin D accelerates resolution of inflammatory responses during tuberculosis treatment. Proc. Natl. Acad. Sci. USA 2012, 109, 15449-15454. [CrossRef] [PubMed]

104. Steinman, R.M.; Banchereau, J. Taking dendritic cells into medicine. Nature 2007, 449, 419-426. [CrossRef] [PubMed]

105. Banchereau, J.; Steinman, R.M. Dendritic cells and the control of immunity. Nature 1998, 392, 245-252. [CrossRef] [PubMed]

106. Hewison, M. An update on vitamin D and human immunity. Clin. Endocrinol. (Oxf.) 2012, 76, 315-325. [CrossRef] [PubMed]

107. Zhang, Y.; Bandala-Sanchez, E.; Harrison, L.C. Revisiting regulatory T cells in type 1 diabetes. Curr. Opin. Endocrinol. Diabetes Obes. 2012, 19, 271-278. [CrossRef] [PubMed]

108. Vickery, B.P.; Scurlock, A.M.; Jones, S.M.; Burks, A.W. Mechanisms of immune tolerance relevant to food allergy. J. Allergy Clin. Immunol. 2011, 127, 576-584. [CrossRef] [PubMed]

109. Hawrylowicz, C.M. Regulatory T cells and IL-10 in allergic inflammation. J. Exp. Med. 2005, 202, 1459-1463. [CrossRef] [PubMed]

110. Tang, Q.; Bluestone, J.A. The FOXP3+ regulatory T cell: A jack of all trades, master of regulation. Nat. Immunol. 2008, 9, 239-244. [CrossRef] [PubMed]

111. La Cava, A. Tregs are regulated by cytokines: Implications for autoimmunity. Autoimmun. Rev. 2008, 8, 83-87. [CrossRef] [PubMed]

112. Chambers, E.S.; Hawrylowicz, C.M. The impact of vitamin D on regulatory T cells. Curr. Allergy Asthma Rep. 2011, 11, 29-36. [CrossRef] [PubMed] 
113. Gorman, S.; Alexandra Kuritzky, L.; Judge, M.A.; Dixon, K.M.; McGlade, J.P.; Mason, R.S.; Finlay-Jones, J.J.; Hart, P.H. Topically applied 1,25-dihydroxyvitamin D3 enhances the suppressive activity of CD4+ CD25+ cells in the draining lymph nodes. J. Immunol. 2007, 179, 6273-6283. [CrossRef] [PubMed]

114. Prietl, B.; Pilz, S.; Wolf, M.; Tomaschitz, A.; Obermayer-Pietsch, B.; Graninger, W.; Pieber, T.R. Vitamin D supplementation and regulatory $\mathrm{T}$ cells in apparently healthy subjects: Vitamin D treatment for autoimmune diseases? Isr. Med. Assoc. J. 2010, 12, 136-139. [PubMed]

115. Jirapongsananuruk, O.; Melamed, I.; Leung, D.Y. Additive immunosuppressive effects of 1,25-dihydroxyvitamin D3 and corticosteroids on TH1, but not TH2, responses. J. Allergy Clin. Immunol. 2000, 106, 981-985. [CrossRef] [PubMed]

116. Van Halteren, A.G.; Tysma, O.M.; van Etten, E.; Mathieu, C.; Roep, B.O. 1alpha,25-dihydroxyvitamin D3 or analogue treated dendritic cells modulate human autoreactive $\mathrm{T}$ cells via the selective induction of apoptosis. J. Autoimmun. 2004, 23, 233-239. [CrossRef] [PubMed]

117. Palmer, M.T.; Lee, Y.K.; Maynard, C.L.; Oliver, J.R.; Bikle, D.D.; Jetten, A.M.; Weaver, C.T. Lineage-specific effects of 1,25-dihydroxyvitamin $\mathrm{D}(3)$ on the development of effector CD4 T cells. J. Biol. Chem. 2011, 286, 997-1004. [CrossRef] [PubMed]

118. Van Belle, T.L.; Gysemans, C.; Mathieu, C. Vitamin D in autoimmune, infectious and allergic diseases: A vital player? Best Pract. Res. Clin. Endocrinol. Metab. 2011, 25, 617-632. [CrossRef] [PubMed]

119. Boonstra, A.; Barrat, F.J.; Crain, C.; Heath, V.L.; Savelkoul, H.F.; O'Garra, A. 1alpha,25-dihydroxyvitamin D3 has a direct effect on naive CD4(+) T cells to enhance the development of TH2 cells. J. Immunol. 2001, 167, 4974-4980. [CrossRef] [PubMed]

120. Mahon, B.D.; Wittke, A.; Weaver, V.; Cantorna, M.T. The targets of vitamin D depend on the differentiation and activation status of CD4 positive T cells. J. Cell. Biochem. 2003, 89, 922-932. [CrossRef] [PubMed]

121. Staeva-Vieira, T.P.; Freedman, L.P. 1,25-dihydroxyvitamin D3 inhibits IFN- $\gamma$ and IL-4 levels during in vitro polarization of primary murine CD4+ T cells. J. Immunol. 2002, 168, 1181-1189. [CrossRef] [PubMed]

122. Khoo, A.L.; Chai, L.; Koenen, H.; Sweep, F.; Joosten, I.; Netea, M.; van der Ven, A. Regulation of cytokine responses by seasonality of vitamin D status in healthy individuals. Clin. Exp. Immunol. 2011, 164, 72-79. [CrossRef] [PubMed]

123. Chen, S.; Sims, G.P.; Chen, X.X.; Gu, Y.Y.; Chen, S.; Lipsky, P.E. Modulatory effects of 1,25-dihydroxyvitamin D3 on human B cell differentiation. J. Immunol. 2007, 179, 1634-1647. [CrossRef] [PubMed]

124. Bohle, B. T lymphocytes and food allergy. Mol. Nutr. Food Res. 2004, 48, 424-433. [CrossRef] [PubMed]

125. Kay, A.B. Allergy and allergic diseases. First of two parts. N. Engl. J. Med. 2001, 344, 30-37. [PubMed]

126. Tan, T.H.T.; Ellis, J.A.; Saffery, R.; Allen, K.J. The role of genetics and environment in the rise of childhood food allergy. Clin. Exp. Allergy 2012, 42, 20-29. [CrossRef] [PubMed] 
127. Lack, G.; Fox, D.; Northstone, K.; Golding, J. Factors associated with the development of peanut allergy in childhood. N. Engl. J. Med. 2003, 348, 977-985. [CrossRef] [PubMed]

128. Palomares, O. The role of regulatory T cells in IgE-mediated food allergy. J. Investig. Allergol. Clin. Immunol. 2013, 23, 371-382. [PubMed]

129. Stone, K.D.; Prussin, C.; Metcalfe, D.D. IgE, mast cells, basophils, and eosinophils. J. Allergy Clin. Immunol. 2010, 125, S73-S80. [CrossRef] [PubMed]

130. Allen, K.J.; Martin, P.E. Clinical aspects of pediatric food allergy and failed oral immune tolerance. J. Clin. Gastroenterol. 2010, 44, 391-401. [CrossRef] [PubMed]

131. Ortolani, C.; Pastorello, E.A. Food allergies and food intolerances. Best Pract. Res. Clin. Gastroenterol. 2006, 20, 467-483. [CrossRef] [PubMed]

132. Berin, M.C.; Sicherer, S. Food allergy: Mechanisms and therapeutics. Curr. Opin. Immunol. 2011, 23, 794-800. [CrossRef] [PubMed]

133. Vickery, B.P.; Chin, S.; Burks, A.W. Pathophysiology of food allergy. Pediatr. Clin. North Am. 2011, 58, 363-376. [CrossRef] [PubMed]

134. Baek, J.H.; Shin, Y.H.; Chung, I.H.; Kim, H.J.; Yoo, E.G.; Yoon, J.W.; Jee, H.M.; Chang, Y.E.; Han, M.Y. The link between serum vitamin D level, sensitization to food allergens, and the severity of atopic dermatitis in infancy. J. Pediatr. 2014, 165, 849-854.e1. [CrossRef] [PubMed]

135. Weisse, K.; Winkler, S.; Hirche, F.; Herberth, G.; Hinz, D.; Bauer, M.; Röder, S.; Rolle-Kampczyk, U.; von Bergen, M.; Olek, S.; et al. Maternal and newborn vitamin D status and its impact on food allergy development in the German LINA cohort study. Allergy 2013, 68, 220-228. [CrossRef] [PubMed]

136. Hinz, D.; Bauer, M.; Roder, S.; Olek, S.; Huehn, J.; Sack, U.; Borte, M.; Simon, J.C.; Lehmann, I.; Herberth, G. Cord blood Tregs with stable FOXP3 expression are influenced by prenatal environment and associated with atopic dermatitis at the age of one year. Allergy 2012, 67, 380-389. [CrossRef] [PubMed]

137. Leyva-Castillo, J.M.; Hener, P.; Jiang, H.; Li, M. TSLP produced by keratinocytes promotes allergen sensitization through skin and thereby triggers atopic march in mice. J. Investig. Dermatol. 2013, 133, 154-163. [CrossRef] [PubMed]

138. Li, M.; Hener, P.; Zhang, Z.; Kato, S.; Metzger, D.; Chambon, P. Topical vitamin D3 and low-calcemic analogs induce thymic stromal lymphopoietin in mouse keratinocytes and trigger an atopic dermatitis. Proc. Natl. Acad. Sci. USA 2006, 103, 11736-11741. [CrossRef] [PubMed]

139. Wjst, M. Introduction of oral vitamin D supplementation and the rise of the allergy pandemic. Allergy Asthma Clin. Immunol. 2009, 5, 8. [CrossRef] [PubMed]

140. Vassallo, M.F.; Camargo, C.A., Jr. Potential mechanisms for the hypothesized link between sunshine, vitamin D, and food allergy in children. J. Allergy Clin. Immunol. 2010, 126, 217-222. [CrossRef] [PubMed]

141. Kong, J.; Zhang, Z.; Musch, M.W.; Ning, G.; Sun, J.; Hart, J.; Bissonnette, M.; Li, Y.C. Novel role of the vitamin $\mathrm{D}$ receptor in maintaining the integrity of the intestinal mucosal barrier. Am. J. Physiol. Gastrointest. Liver Physiol. 2008, 294, G208-G216. [CrossRef] [PubMed] 
142. Clairmont, A.; Tessmann, D.; Stock, A.; Nicolai, S.; Stahi, W.; Sies, H. Induction of gap junctional intercellular communication by vitamin $\mathrm{D}$ in human skin fibroblasts is dependent on the nuclear vitamin D receptor. Carcinogenesis 1996, 17, 1389-1391. [CrossRef] [PubMed]

143. Pálmer, H.G.; González-Sancho, J.M.; Espada, J.; Berciano, M.T.; Puig, I.; Baulida, J.; Quintanilla, M.; Cano, A.; de Herreros, A.G.; Lafarga, M.; et al. Vitamin D3 promotes the differentiation of colon carcinoma cells by the induction of E-cadherin and the inhibition of $\beta$-catenin signaling. J. Cell Biol. 2001, 154, 369-388. [CrossRef] [PubMed]

144. Gniadecki, R.; Gajkowska, B.; Hansen, M. 1,25-dihydroxyvitamin D3 stimulates the assembly of adherens junctions in keratinocytes: Involvement of protein kinase C. Endocrinology 1997, 138, 2241-2248. [CrossRef] [PubMed]

145. Schwalfenberg, G.K. A review of the critical role of vitamin D in the functioning of the immune system and the clinical implications of vitamin D deficiency. Mol. Nutr. Food Res. 2011, 55, 96-108. [CrossRef] [PubMed]

146. Szeles, L.; Keresztes, G.; Torocsik, D.; Balajthy, Z.; Krenacs, L.; Poliska, S.; Steinmeyer, A.; Zuegel, U.; Pruenster, M.; Rot, A.; et al. 1,25-dihydroxyvitamin D3 is an autonomous regulator of the transcriptional changes leading to a tolerogenic dendritic cell phenotype. J. Immunol. 2009, 182, 2074-2083. [CrossRef] [PubMed]

147. Heine, G.; Niesner, U.; Chang, H.D.; Steinmeyer, A.; Zugel, U.; Zuberbier, T.; Radbruch, A.; Worm, M. 1,25-dihydroxyvitamin $\mathrm{D}(3)$ promotes IL-10 production in human B cells. Eur. J. Immunol. 2008, 38, 2210-2218. [CrossRef] [PubMed]

148. Curotto de Lafaille, M.A.; Lafaille, J.J. Natural and adaptive FOXP3+ regulatory T cells: More of the same or a division of labor? Immunity 2009, 30, 626-635. [CrossRef] [PubMed]

149. Kanjarawi, R.; Dercamp, C.; Etchart, N.; Adel-Patient, K.; Nicolas, J.F.; Dubois, B.; Kaiserlian, D. Regulatory $\mathrm{T}$ cells control type I food allergy to beta-lactoglobulin in mice. Int. Arch. Allergy Immunol. 2011, 156, 387-396. [CrossRef] [PubMed]

150. Adel-Patient, K.; Wavrin, S.; Bernard, H.; Meziti, N.; Ah-Leung, S.; Wal, J.M. Oral tolerance and Treg cells are induced in BALB/c mice after gavage with bovine beta-lactoglobulin. Allergy 2011, 66, 1312-1321. [CrossRef] [PubMed]

151. Ruiter, B.; Shreffler, W.G. The role of dendritic cells in food allergy. J. Allergy Clin. Immunol. 2012, 129, 921-928. [CrossRef] [PubMed]

152. Heine, G.; Anton, K.; Henz, B.M.; Worm, M. 1alpha,25-dihydroxyvitamin D3 inhibits anti-CD40 plus IL-4-mediated IgE production in vitro. Eur. J. Immunol. 2002, 32, 3395-3404. [PubMed]

153. Hartmann, B.; Heine, G.; Babina, M.; Steinmeyer, A.; Zügel, U.; Radbruch, A.; Worm, M. Targeting the vitamin D receptor inhibits the B cell-dependent allergic immune response. Allergy 2011, 66, 540-548. [CrossRef] [PubMed]

154. Matheu, V.; Back, O.; Mondoc, E.; Issazadeh-Navikas, S. Dual effects of vitamin D-induced alteration of TH1/TH2 cytokine expression: Enhancing IgE production and decreasing airway eosinophilia in murine allergic airway disease. J. Allergy Clin. Immunol. 2003, 112, 585-592. [CrossRef] 
155. Rothers, J.; Wright, A.L.; Stern, D.A.; Halonen, M.; Camargo, C.A., Jr. Cord blood 25-hydroxyvitamin D levels are associated with aeroallergen sensitization in children from Tucson, Arizona. J. Allergy Clin. Immunol. 2011, 128, 1093-1099.e5. [CrossRef] [PubMed]

156. Vie Streym, S.; Kristine Moller, U.; Rejnmark, L.; Heickendorff, L.; Mosekilde, L.; Vestergaard, P. Maternal and infant vitamin D status during the first 9 months of infant life-a cohort study. Eur. J. Clin. Nutr. 2013, 67, 1022-1028. [CrossRef] [PubMed]

157. Delvin, E.E.; Glorieux, F.H.; Salle, B.L.; David, L.; Varenne, J.P. Control of vitamin D metabolism in preterm infants: Feto-maternal relationships. Arch. Dis. Child. 1982, 57, 754-757. [CrossRef] [PubMed]

(C) 2015 by the authors; licensee MDPI, Basel, Switzerland. This article is an open access article distributed under the terms and conditions of the Creative Commons Attribution license (http://creativecommons.org/licenses/by/4.0/). 